\title{
Deskripsi Kegiatan Disertai Identifikasi Potensi dan Kendala Kelompok Tani dalam Usahatani Mangga (Studi Kasus di Kelompok Tani Datar Indah dan Samoja)
}

\author{
Elly Rasmikayati ${ }^{1}$, Endah Djuwendah ${ }^{2}$, Gema Wibawa Mukti ${ }^{3}$, Bobby Rachmat \\ Saefudin $^{4}$, Fitriana Wati ${ }^{5}$ \\ 1,2,3,5 Program Studi Agribisnis, Fakultas Pertanian, Universitas Padjadjaran \\ ${ }^{4}$ Program Studi Agribisnis, Fakultas Pertanian, Ma'soem University

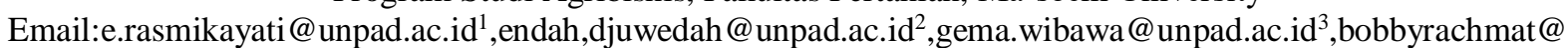 \\ masoemuniverity.ac.id ${ }^{4}$,fitriaw241@ gmail.com ${ }^{5}$
}

\begin{abstract}
ABSTRAK
Kelompok tani merupakan sebuah lembaga yang memiliki fungsi untuk memfasilitasi petani dalam melakukan kegiatan agribisnis dari hulu hingga hilir. Namun pada kenyataannya, harapan mengenai fungsi kelompok tani belum sepenuhnya terwujud. Penelitian ini bertujuan untuk: 1) Mendeskripsikan kegiatan kelompok tani dalam menjalankan fungsinya pada usahatani mangga di Kecamatan Sedong; dan 2) Mengidentifikasi apa saja potensi dan kendala yang dihadapi oleh kelompok tani dalam kegiatan usahatani mangga. Penelitian ini dilakukan di dua kelompok tani yang berbeda di Kecamatan Sedong, Kabupaten Cirebon yaitu Kelompok Tani Datar Indah dan Kelompok Tani Samoja dengan total responden sebanyak 45 responden. Teknik analisis data yang digunakan dalam penelitian ini adalah analisis data primer dan sekunder. Hasil penelitian menunjukkan, pada kelompok tani Datar Indah dalam satu tahun terdapat 15 kegiatan yang dilakukan bersama, terdiri dari pertemuan anggota, penyuluhan, dan penyaluran bantuan. Namun sebanyak $70 \%$ anggota hanya mengikuti kegiatan sebanyak 6-10 kali dalam satu tahun. Sedangkan kelompok tani Samoja mengadakan kegiatan yang sama dengan poktan Datar Indah dengan jumlah rata-rata 10 kali dalam satu tahun di mana hampir $60 \%$ anggotanya mengikuti sebanyak 4-6 kali dalam satu tahun. Sementara itu, potensi yang dimiliki oleh kedua kelompok tani adalah peningkatan daya tawar petani, mempercepat pemecahan masalah, dan pengenalan teknologi baru. Sedangkan kendala yang dialami oleh kelompok tani berupa kurangnya motivasi petani, kurangnya kesadaran akan peran kelompok tani, kesibukan petani, dan kurangnya tenaga penyuluh.
\end{abstract}

Kata Kunci: Kegiatan usahatani, potensi, kendala, kelompok tani, usahatani mangga, penyuluhan, pelatihan.

\section{PENDAHULUAN}

Jawa Barat sebagai salah satu sentra penghasil mangga nasional memiliki keunikan dimana kebun mangga terpusat pada beberapa daerah yang berdekatan, yaitu Kabupaten Indramayu, Kabupaten Cirebon, Kabupaten Kuningan, Kabupaten Majalengka, dan Kabupaten Sumedang. Hal tersebut dikarenakan kondisi agroklimat dan lahan yang paling potensial untuk pengembangan agribisnis mangga. Berdasarkan Badan Pusat Statistik (2018), pada tahun 2017 Kabupaten Cirebon merupakan sentra penghasil mangga terbesar ketiga di Jawa Barat dengan kontribusi produksi mangga sekitar $12 \%$ terhadap produksi mangga Jawa Barat setelah Kabupaten Indramayu (26\%) dan Kabupaten Majalengka (18\%). Kabupaten Cirebon juga merupakan daerah yang potensial untuk pengembangan agribisnis mangga.

Program tersebut berupa pengembangan inovasi agribisnis mangga menjadi horti park Kementerian Pertanian yang bekerjasama dengan salah satu petani di Kecamatan Sedong. Program inovasi dilakukan mulai tahun 2014 dengan membangun demplot kebun percontohan dengan penerapan inovasi teknologi berupa manajemen pengelolaan kebun mangga mulai dari budidaya 
hingga pasca panen, yang bertujuan untuk meningkatkan kualitas buah mangga yang dihasilkan (Puslitbang Hortikultura, 2017).

Tabel 1. Jumlah Pohon dan Luas Area Penanaman Pohon Mangga di Kabupaten Cirebon

\begin{tabular}{clccc}
\hline No & Kecamatan & Jumlah Pohon & Luas (Ha) & $\begin{array}{c}\text { Kontribusi } \\
(\%)\end{array}$ \\
\hline 1 & Sedong & 130.805 & 1.308 & 37 \\
2 & Dukupuntang & 82.500 & 825 & 23 \\
3 & Greged & 69.000 & 690 & 19 \\
4 & Lemahabang & 49.259 & 492 & 14 \\
5 & Astanajapura & 15.700 & 157 & 4 \\
6 & Sumber & 7.070 & 71 & 2 \\
\hline & Jumlah & 354.334 & 3.543 & 100 \\
\hline
\end{tabular}

Sumber: Distanbunakhut Kab. Cirebon, 2015 dalam Rasmikayati dkk. (2018), diolah

Dengan adanya kelompok tani, petani yang tergabung didalamnya dapat memperoleh informasi, tambahan pengetahuan, bantuan akses pemasaran, dan lainnya yang dapat mempermudah petani. Berdasarkan fungsi yang dimilikinya kelompok tani juga diharapkan dapat meningkatkan produktivitas dan daya tawar petani sehingga dapat meningkatkan tingkat kesejahteraan petani, salah satunya melalui adopsi teknologi.

Terdapat beberapa permasalahan yang ditemukan dalam berjalannya kelompok tani seperti kurangnya pembinaan, keterbatasan pengetahuan dan informasi anggota, kurangnya aspek pemeliharaan kelompok tani, dan tidak tercapainya tujuan kelompok. Pencapaian tujuan kelompok merupakan gambaran kedinamisan kelompok tersebut, sehingga mengindikasikan bahwa kelompok tani belum menjalankan perannya secara optimal untuk penerapan teknologi yang bertujuan meningkatkan pendapatan petani yang tergabung didalamnya. Berdasarkan uraian tersebut, penelitian ini bertujuan untuk: 1) Mendeskripsikan kegiatan kelompok tani dalam menjalankan fungsinya pada usahatani mangga di Kecamatan Sedong; dan 2) Mengidentifikasi apa saja potensi dan kendala yang dihadapi oleh kelompok tani dalam kegiatan usahatani mangga.

\section{METODE PENELITIAN}

\section{Lokasi Penelitian}

Penelitian ini dilakukan di dua kelompok tani yang berbeda di Kecamatan Sedong yaitu Kelompok Tani Datar Indah dan Kelompok Tani Samoja. Keduanya ditentukan secara purposive dengan pertimbangan bahwa Kelompok tani Datar Indah cenderung lebih aktif dibandingkan dengan kelompok tani Samoja, sehingga diharapkan nantinya terdapat hal-hal positif yang dapat dicontoh kelompok tani lain agar lebih berkembang.

\section{Desain dan Metode Penelitian}

Desain penelitian dalam penelitian ini adalah desain mix method, yaitu kombinasi antara desain kuantitatif dan kualitatif. Sedangkan metode penelitian yang digunakan dalam penelitian ini adalah metode survey. Metode survey merupakan metode yang mempunyai tujuan untuk memberikan gambaran atau penjelasan mengenai sesuatu dan bertujuan untuk melakukan analisis (Soehartono, 2000 dalam Amin, 2011).

\section{Variabel Penelitian}

1. Kegiatan kelompok tani, merupakan aktivitas yang dilakukan kelompok tani dalam kegiatan usahatani mangga. Kegiatan kelompok tani terdiri dari variabel-variabel berikut:

a. Partisipasi anggota, menggambarkan jumlah keterlibatan seorang anggota dalam seluruh kegiatan yang terdapat dalam kelompok.

b. Program PAH/IHDUA, program pengembangan agribisnis manggga yang berasal dari dana hibah pemerintah jepang.

c. Penyuluhan GAP, sosialisasi mengenai pentingnya penerapan GAP dalam usahatani mangga. 
d. Penyuluhan pengendalian lalat buah, merupakan kegiatan penyuluhan untuk mengatasi serangan hama lalat buah.

e. Program ALPP, merupakan program yang bertujuan untuk mengendalikan serangan hama lalat buah hingga batas terendah menggunakan dalam suatu kawasan.

f. Penyuluhan rutin, yaitu penyuluhan yang dilakukan penyuluh pada setiap kelompok tani biasanya dalam jangka waktu 1 atau 2 bulan sekali.

g. Alokasi bantuan saprotan, merupakan program tahunan dari pemerintah yang memberikan bantuan berupa saprotan melalui kelompok tani.

h. Pertemuan anggota kelompok, merupakan kegiatan mandiri yang direncanakan anggota tanpa campur tangan pihak lain.

2. Potensi dan kendala yang dihadapi kelompok tani, merupakan keadaan yang mempunyai kemungkinan untuk dikembangkan dan keadaan yang dapat menjadi penghambat petani dan kelompok tani dalam produksi.

\section{Sumber dan Teknik Pengumpulan Data} berikut:

Data yang dikumpulkan dalam penelitian ini meliputi data primer dan data sekunder sebagai

1. Data primer

a. Observasi

Observasi merupakan kegiatan pemuatan penelitian terhadap suatu objek.

b. Wawancara

Wawancara merupakan kegiatan tanya jawab antara peneliti dengan responden atau informan lainnya. Responden dalam penelitian ini adalah seluruh anggota kedua kelompok tani yang masih aktif yaitu sebanyak 45 responden, terdiri dari 23 responden anggota Kelompok Tani Datar Indah dan 22 responden anggota Kelompok Tani Samoja.

\section{Data Sekunder}

Data sekunder diperoleh melalui literatur yang berkaitan dengan penelitian. Data sekunder juga dapat diperoleh melalui penelitian terdahulu, laporan perusahaan, dan laporan lembaga pemerintahan, dan lainnya.

\section{Teknik Analisis Data}

Teknik analisis data adalah metode untuk menjawab tujuan penelitian. Teknik analisis data yang digunakan dalam penelitian ini adalah analisis statistika deskriptif berupa distribusi frekuensi untuk data kuantitatif (data responden) dan analisis eksploratif berdasarkan informasi yang data primer lainnya seperti dari informan dan data sekunder.

\section{HASIL DAN PEMBAHASAN}

\section{Deskripsi Kegiatan Kelompok Tani}

Kelompok Tani Datar Indah dan Kelompok Tani Samoja merupakan kelompok tani yang terdapat pada Kecamatan Sedong. Kedua kelompok memiliki letak kebun pada satu hamparan yang sama, yang berlokasi pada Desa Karangwuni. Kelompok Datar Indah dan Samoja didirikan semenjak adanya program penanaman mangga PAH tepatnya pada tahun 1999. Pada awalnya kelompok tani didirikan berdasarkan perintah dari Dinas Pertanian. Kelompok tani dibentuk berdasarkan lokasi kebun yang dimiliki. Kelompok Tani Datar Indah merupakan kelompok yang anggotanya terletak pada Desa Karangwuni yang diketuai oleh Karma. Saat ini sudah dilakukan dua kali terjadi pergantian ketua kelompok. Pada awal pembentukan kelompok, terdapat struktur organisasi kelompok yang terdiri dari Ketua, Wakil, Sekretaris, Bendahara, dan anggota. Berikut deskripsi jumlah partisipasi anggota di kedua kelompok dalam mengikuti kegiatan yang diselenggarakan: 
Tabel 2. Jumlah Partisipasi Anggota dalam Kegiatan Kelompok Tani

\begin{tabular}{|c|c|c|c|}
\hline Kelompok Tani & $\begin{array}{c}\text { Jumlah Partisipasi Anggota dalam } \\
\text { Kegiatan Kelompok }\end{array}$ & Frekuensi (Orang) & Presentase $(\%)$ \\
\hline \multirow[t]{4}{*}{ Datar Indah } & $0-5 \mathrm{kali} / \mathrm{tahun}$ & 4 & 17 \\
\hline & 6-10 kali/tahun & 16 & 70 \\
\hline & $11-15 \mathrm{kali} / \mathrm{tahun}$ & 3 & 13 \\
\hline & Jumlah & 23 & 100 \\
\hline \multirow[t]{4}{*}{ Samoja } & $0-3$ kali/tahun & 2 & 9 \\
\hline & 4-6 kali/tahun & 13 & 59 \\
\hline & 7-10 kali/tahun & 7 & 32 \\
\hline & Jumlah & 22 & 100 \\
\hline
\end{tabular}

Sumber: Data primer, diolah (2020)

Adapun beberapa kegiatan yang dilakukan oleh kedua kelompok diantaranya adalah Program PAH/IHDUA, penyuluhan GAP, penyuluhan off season, penyuluhan pengendalian lalat buah, program ALPP, penyuluhan rutin oleh penyuluh, alokasi bantuan saprotan, dan pertemuan anggota kelompok.

\section{Program PAH/IHDUA}

Kecamatan Sedong merupakan salah satu wilayah yang masuk dalam program PAH/IHDUA (Pengembangan Agribisnis Hortikultura/ Intergrated Horticulture Development in Upland Area). Program ini dilakukan pada 5 kecamatan, yaitu Kecamatan Beber, Kecamatan Losari, Kecamatan Sedong, Kecamatan Cirebon Selatan, dan Kecamatan Astanajapura. Program PAH/IHDUA merupakan program pengembangan mangga dengan komoditas gedong gincu yang dibiayai dana hibah pemerintah Jepang yang dilaksanakan pada tahun 1997-2000. Luas area yang dikembangkan adalah sebesar 600 Ha. Pada Kelompok Datar Indah terdapat 55 orang petani yang mengikuti program.

Sedangkan pada Kelompok Samoja terdapat 45 petani yang mengikuti kegiatan. Sekitar $80 \%$ petani di kedua kelompok sebelumnya tidak pernah melakukan usahatani mangga. Sebelumnya mayoritas dari mereka adalah petani padi. Hal ini sesuai dengan penelitian Saefudin dkk. (2019) yang mengatakan bahwa melalui program ini mayoritas petani yang awalnya merupakan petani padi mulai melakukan usahatani mangga. Pada Kelompok Datar Indah jumlah luas lahan yang termasuk dalam program ini adalah seluas $55 \mathrm{Ha}$ dan Kelompok Samoja seluas $30 \mathrm{Ha}$. Perbedaan luas lahan dikarenakan jumlah petani yang memiliki lahan untuk ditanami komoditas mangga pada Kelompok Datar Indah lebih banyak dibanding Kelompok Samoja. Melalui program tersebut petani diberikan bibit mangga yang disesuaikan dengan luas lahan yang dimiliki. Petani yang memiliki luas lahan $1 \mathrm{Ha}$ diberikan bibit dengan jumlah 100 pohon. Namun apabila terdapat pohon yang rusak atau mati pada saat penanaman petani diperbolehkan untuk meminta bibit tambahan. Selain pemberian bibit, petani juga mendapatkan pendampingan serta bantuan saprotan untuk melakukan kegiatan usahatani mangga

\section{Penyuluhan GAP (Good Agriculture Practice)}

Penyuluhan GAP dilakukan pada kelompok Datar Indah dan Samoja pada tahun 2017 yang diadakan oleh Dinas Pertanian Jawa Barat. Penyuluhan dilakukan dengan tujuan untuk meningkatkan pengetahuan dan kemampuan petani dalam menjalankan kegiatan usahatani mangga sesuai prosedur yang baik dan benar. Dengan dilakukan penerapan GAP diharapkan hasil panen yang diperoleh meningkat karena dilakukan dengan sesuai prosedur. Tujuan tersebut sesuai dengan hasil penelitian Hartanti (2010) yang menyebutkan bahwa terdapat perbedaan diantara petani yang menerapkan GAP dan non GAP, dimana pendapatan total usahatani mangga gedong gincu dengan penerapan GAP lebih besar dan $\mathrm{R} / \mathrm{C}$ rasio juga lebih besar dibandingkan petani yang tidak menerapkan. 


\section{Penyuluhan Off Season}

Penyuluhan Off Season yang dilakukan hanya pada kelompok tani Samoja pada tahun 2018. Penyuluhan diselenggarakan oleh Dinas Pertanian Kabupaten Cirebon. Penyuluhan ini dilakukan dengan metode penyuluhan kelompok. Penyuluhan off season dilakukan hanya satu kali dan diikuti

oleh 18 anggota kelompok. Adapun dalam penyuluhan ini membahas perlakuan apa saja yang diterapkan dalam teknologi off season. Penyuluhan meliputi bahasan cara pemupukan, pemangkasan, pembersihan lahan, penanganan OPT, pemberian ZPT, dan pemeliharaan.

Menurut pendapat petani, faktor utama yang menghambat petani dalam penerapan off season adalah biaya produksi yang tinggi. Dinas Pertanian terus memotivasi petani bahwa hasil yang diperoleh dari penerapan off season akan menutup biaya produksi. Dinas Pertanian juga menawarkan pilihan untuk membantu petani yang ingin melakukan pinjaman kredit yang nantinya akan didampingi oleh penyuluh. Namun mayoritas petani mangga menggunakan modal pribadi dalam menjalankan usahatani. Sebanyak lebih dari $95 \%$ petani dari kedua kelompok masih menggunakan modal pribadi tanpa melakukan pinjaman ke lembaga keuangan setempat.

\section{Penyuluhan Teknik Pengendalian Lalat Buah}

Penyuluhan teknik pengendalian lalat buah yang dilakukan hanya pada Kelompok Datar Indah. Penyuluhan dilakukan oleh Universitas Padjajaran pada tahun 2018. Tujuan dilakukannya penyuluhan ini adalah sebagai upaya penanganan hama lalat buah yang cukup mengkhawatirkan. Penyuluhan diikuti oleh 17 petani atau sebanyak 73\% dari total seluruh anggota kelompok. Penyuluhan dilakukan hanya satu kali selama 3 jam dengan metode penyuluhan kelompok. Penyuluhan dilakukan secara dua arah, dimana petani dapat menanyakan pendapat akademisi mengenai permasalahan lalat buah atau permasalahan lain yang dihadapi. Dalam penyuluhan tersebut membahas mengenai pengenalan lalat buah serta beberapa cara yang dapat digunakan untuk mengatasinya. Namun saat ini petani belum banyak menggunakan teknologi untuk mengatasi lalat buah. Hampir seluruh petani di Kecamataan Sedong mengatasi permasalahan lalat buah dengan menggunakan perangkap lalat. Petani menjelaskan bahwa lalat buah merupakan hama yang sudah menyerang sejak lama dan belum dapat ditangani sepenuhnya. Oleh karena itu dirasa masih perlu dilakukan penerapan teknologi baru dalam mengatasi permasalahan hama lalat buah dan melakukan penyemprotan.

\section{Penyuluhan ALPP (Areas of Low Pest Prevalence)}

Areas of Low Pest Prevalence atau disebut ALPP merupakan suatu area yang memiliki ambang batas tertentu dan diusahakan hama yang menyerang hingga tingkat terendah. Program ALPP dilakukan pada kelompok tani datar Indah dan Samoja. Program ALPP diselenggarakan oleh Dinas Pertanian Jawa Barat pada tahun 2017. Program ini dilakukan dengan tujuan untuk pengendalian lalat buah secara serentak dalam satu kawasan. Penyuluhan diberikan langsung oleh petugas dari Dinas Pertanian provinsi. Penyuluhan serentak dilakukan sebanyak satu kali. Meskipun partisipasi petani mencapai $100 \%$ dalam program ini, namun pada tahap sosialisasi tidak seluruh anggota mengikuti, dimana jumlah partisipasi petani dalam mengikuti sosialisasi sebesar 95\% anggota dari kedua kelompok.

\section{Penyuluhan Rutin}

Penyuluhan rutin dilakukan pada kedua kelompok dan seluruh kelompok tani di Kecamatan Sedong. Biasanya satu kelompok tani mendapat penyuluhan sebanyak satu kali dalam satu bulan. Penyuluhan rutin dilakukan oleh penyuluh yang bertugas mendampingi kelompok. Anggota Kelompok Datar Indah lebih banyak yang mengikuti penyuluhan rutin dibanding Kelompok Samoja. Kelompok Datar Indah dalam satu kali penyuluhan rata-rata diikuti oleh 18 anggota atau partisipasi anggota sebanyak $78 \%$. Sedangkan pada Kelompok Samoja dalam satu kali penyuluhan rata-rata diikuti oleh 15 petani atau sebanya $68 \%$ dari keseluruhan anggota. Pembahasan dalam penyuluhan 
rutin disesuaikan dengan permasalahan budidaya yang sedang dihadapi oleh petani. Penyuluhan rutin dilakukan dengan metode penyuluhan kelompok dan penyuluhan anjangsono atau penyuluhan individu. Penyuluhan kelompok biasanya dilakukan pada salah satu rumah anggota, sedangkan penyuluhan individu dilakukan langsung secara perorangan di kebun petani. Terdapat beberapa metode penyuluhan yang dilakukan penyuluh di Kecamatan Sedong khususnya pada Kelompok Tani Datar Indah dan Samoja, diantaranya adalah:

a. Penyuluhan kelompok

Penyuluhan kelompok dilakukan melalui pertemuan bersama antara penyuluh dengan anggota salah satu kelompok. Penyuluhan ini hanya dilakukan pada satu kelompok dan tidak digabung dengan kelompok lain. Biasanya penyuluhan kelompok dilakukan tiap bulan. Jumlah petani yang mengikuti penyuluhan kelompok tidak tetap, namun rata-rata setiap penyuluhan diikuti oleh lebih dari $70 \%$ anggota. Lokasi penyuluhan kelompok sangat fleksibel, biasanya dilakukan pada salah satu rumah naggota, TPP, atau balai desa. Tiga hari sebelum dilakukan penyuluhan, ketua kelompok memberikan pemberitahuan kepada anggota.

b. Penyuluhan demplot

Penyuluhan demplot biasanya dilakukan pada saat ada program yang melibatkan beberapa kelompok tani. Demontration Plot atau Demplot merupakan suatu penyuluhan dengan membuat lahan percontohan. Penyuluhan demplot biasanya diikuti oleh minimal dua kelompok, walaupun tidak semua anggota kelompok tersebut hadir. Biasanya penyuluhan demplot diikuti oleh lebih dari 40 petani. Presentase kehadiran tiap anggota kelompok berkisar 60\%. Penyuluhan demplot biasanya tidak hanya dilakukan oleh penyuluh setempat.

c. Penyuluhan Anjangsono

Penyuluhan angjangsono merupakan nama lain dari penyuluhan individu. Penyuluhan anjangsono dilakukan dengan mendatangi langsung petani di kebun untuk melakukan konsultasi dengan penyuluh. Metode penyuluhan angjangsono dilakukan karena tidak semua anggota hadir dalam penyuluhan kelompok. Oleh karena itu, agar penyuluhan merata dilakukan kunjungan langsung ke petani. Petani memiliki jadwal kunjungan yang tidak menentu karena keterbatasan tenaga penyuluh yang harus mendampingi beberapa kelompok.

\section{Pertemuan Anggota Kelompok}

Pertemuan anggota kelompok di kedua kelompok tani memiliki karakteristik yang berbeda. Pada Kelompok Datar Indah pertemuan anggota kelompok dilakukan 1 bulan sekali, bahkan terkadang jika dirasa ada hal yang perlu dibicarakan pertemuan anggota dapat dilakukan hingga 2 kali dalam satu bulan. Sedangkan pada Kelompok Samoja pertemuan anggota dilakukan 2 bulan sekali. Jumlah partisipasi anggota dalam pertemuan kelompok juga berbeda satu sama lain. Rata-rata partisipasi anggota Kelompok Datar Indah pada pertemuan antar anggota adalah sebesar 82\% atau 19 anggota, sedangkan Kelompok Samoja sebesar $72 \%$ atau 17 anggota. Karma dan Herman sebagai ketua kelompok menjelaskan bahwa pertemuan dilakukan sebagsai sarana silaturahmi dan saling bertukar informasi sesama anggota. Pertemuan antar anggota biasanya juga membahas permasalahan yang ditemui atau jenis input pertanian terbaru yang berfungsi untuk meningkatkan produksi.

\section{Program Bantuan}

Penyaluran bantuan diatur dalam Peraturan Menteri Pertanian No. 5 Tahun 2013 Tentang Pedoman Pengelolaan dan Pertanggung jawaban Belanja Bantuan Sosial Kementerian Pertanian Tahun Anggaran 2013. Dalam peraturan tersebut tertulis bahwa pengadaan program bertujuan untuk penanggulangan kemiskinan pada petani, serta untuk melakukan pemberdayaan sosial dalam bentuk uang atau barang agar secara mandiri dan bersama-sama meningkatkan produktivitas, nilai tambah dan daya saing produk pertanian yang akan meningkatkan kesejahteraan masyarakat petani. Mekanisme penetapan pemberian bantuan dilakukan dengan cara melakukan perencanaan dan sosialisasi, menentukan calon penerima, penetapan penerima bantuan, dan selanjutnya dilakukan realisasi 
pengadaan bantuan. Adapun bantuan yang pernah diterima oleh Kelompok Tani Datar Indah dan Kelompok Tani Samoja adalah bantuan tahunan dan bantuan yang berasal dari TPP:

\section{a. Bantuan Tahunan}

Bantuan tahunan merupakan bantuan yang diterima kelompok setiap satu tahun dan berlaku untuk kedua kelompok. Bantuan biasanya diperoleh dari Dinas Pertanian baik Dinas Pertanian pusat, provinsi, ataupun kabupaten. Kedua kelompok mendapatkan bantuan yang sama karena kebun yang dimiliki berada pada satu hamparan, hanya saja jumlah kuantitas yang diberikan berbeda. Bantuan tahunan yang diterima oleh kedua kelompok berupa bantuan bibit dan pupuk.

Adapun jumlah bibit yang diberikan berdasarkan luas lahan yang dimiliki petani. Semakin luas lahan yang dimiliki maka semakin banyak jumlah bibit yang diperoleh. Biasanya tiap pembukaan luas lahan baru sebesar 0,5 Ha diberikan bibit sebanyak 60 buah. Jumlah bibit yang diberikan pada tiap kelompok per tahunnya rata-rata 200 buah.

Selain pemberian bibit, bantuan tahunan lainnya adalah pupuk. Kedua kelompok tani mendapatkan tiga jenis pupuk, yaitu pupuk organik, pupuk NPK, dan POC. Berbeda dengan pemberian bibit, pemberian pupuk dilakukan secara merata kepada 45 petani atau sebanyak $100 \%$ anggota di kedua kelompok. Kelompok Datar Indah menerima $600 \mathrm{~kg}$ pupuk NPK, 2 ton pupuk organik, dan 2 kardus POC. Sedangkan Kelompok Samoja menerima $400 \mathrm{~kg}$ pupuk NPK, 1 ton pupuk organik, dan 2 kardus POC

\section{b. Bantuan dari TPP}

TPP merupakan salah satu hasil dari program yang dilakukan oleh Dinas Pertanian Pusat. TPP dibangun pada tahun 2015 dan sudah beroperasi sejak tahun 2018. TTP merupakan sarana yang diperuntukkan kepada seluruh kelompok tani yang berada di Kabupaten Cirebon. Adapun fungsi TPP adalah sebagai media pembelajaran petanii, pusat penelitian, pengembangan teknologi, pusat kegiatan agribisnis, dan sebagai tempat pembelajaran bagi siswa atau mahasiswa. Alokasi bantuan diberikan berdasarkan luas lahan yang dimiliki petani. Kelompok Datar Indah menerima 100 ton pupuk organik, 6 ton pupuk NPK, 4.000 bibit mangga, dan 10 kardus pestisida. Sedangkan Kelompok Samoja menerima 50 ton pupuk organik, 3 ton pupuk NPK, 2.000 bibit mangga, dan 5 kardus pestisida. Penyaluran bantuan dilakukan dari DInas Pertnian pusat melalui TTP.

\section{Potensi dan Kendala yang Dihadapi Kelompok Tani}

\section{Potensi}

\section{Peningkatan Daya Tawar Petani}

Daya tawar merupakan kekuatan atau pengaruh yang dimiliki salah satu pihak dalam menjalankan negosiasi bisnis. Kelompok tani merupakan salah satu wadah berkumpulnya petani untuk melakukan pertukaran informasi dan kegiatan lainnya. Beberapa permasalahan yang sering dihadapi petani adalah ketidak pastian pasar dan harga yang berfluktuasi. Rendahnya harga yang diperoleh petani pada saat musim panen raya akan mempengaruhi pendapatan petani. Salah satu cara mengatasi permasalahan tersebut adalah dengan membentuk kesatuan gabungan petani untuk bersama-sama mengusahakan perbaikan pasar dengan meningkatkan kuantitas dan kualitas. Perbaikan kuantitas dan kualitas dapat dilakukan bersama gabungan kelompok tani didampingi oleh pemerintah setempat. Dengan demikian pemasaran mangga dapat menjangkau tidak hanya pasar lokal, namun hingga ritel dan pasar ekspor.

\section{Mempercepat Pemecahan Masalah}

Salah satu kegiatan kelompok tani adalah pertemuan rutin antar anggota. Melalui pertemuan tersebut anggota kelompok saling bertukar informasi mengenai hal baru yang menunjang kegiatan usahatani mangga, maupun permasalahan yang sedang dihadapi. Petani yang sudah mendapatkan solusi dari permasalahan tersebut selanjutnya berbagi informasi kepada anggota yang lain. Hal tersebut merupakan salah satu keuntungan dengan bergabung bersama kelompok tani. Kelompok tani berfungsi 
dalam membantu memperlancar proses dalam mengidentifikasi kebutuhan dan masalah serta menyusun rencana dan memecahkan masalah yang dihadapi dalam usahataninya.

\section{Pengenalan Teknologi Baru}

Salah satu faktor penting dalam kegiatan usahatani adalah penerapan teknologi. Dalam penelitian Apriani dkk. (2018), diketahui bahwa penerapan teknologi dalam pertanian dapat berpengaruh terhadap peningkatan efisiensi dan produktivitas hasil. Teknologi pertanian adalah alat, cara atau metode yang digunakan dalam mengolah atau memproses input pertanian sehingga menghasilkan output atau hasil pertanian sehingga berdaya guna dan berhasil guna baik berupa produk bahan mentah, setengah jadi maupun siap pakai (Ali, 2015). Beberapa teknologi yang sudah diterapkan dalam kegiatan usaaha tani mangga di Kecamatan Sedong yang adalah teknologi off season, namun saat ini belum banyak diterapkan inovasi teknologi baru.

\section{Kendala}

\section{Kurangnya Motivasi Petani}

Mayoritas petani responden adalah petani yang berusia tua, sehingga memiliki sikap kurangnya keterbukaan akan hal baru. Petani biasanya melakukan budidaya mangga berdasarkan pengalaman dan pengetahuan yang diperoleh dari kelompok. Padahal sumber informasi tidak hanya berasal dari pertemuan langsung saja. Namun kini terdapat berbagai kemudahan untuk mengakses informasi melalui internet. Internet dapat digunakan petani sebagai media penunjang melakukan usahatani mangga, baik dalam mencari informasi mengenai teknik budidaya, penanganan hama, harga pasar, dan lainnya. Kurangnya motivasi petani juga dipengaruhi oleh luasan lahan yang dimiliki. Petani dengan jumlah pohon dan luas lahan yang lebih besar cenderung akan lebih memperhatikan dan melakukan pemeliharaan dengan baik dibanding petani yang memiliki jumlah pohon dan luas lahan yang lebih kecil (Rasmikayati dkk, 2018).

\section{Kurangnya Kesadaran Terhadap Fungsi Kelompok Tani}

Salah satu faktor yang dapat memperlancar pembangunan pertanian adalah adanya kesadaran individu, dengan adanya kesadaran individu tersebut petani bergabung ke dalam suatu wadah yaitu kelompok tani (Puspitaningsih dkk, 2016). Sebagian petani menganggap kelompok tani hanya sebagai media berkumpul dan bermusyawarah sesama anggota. Namun sebenarnya fungsi kelompok tani bukan hanya tempat berkumpulnya sesama petani. Kelompok tani merupakan kesatuan unit yang apabila dijalankan dengan baik dapat meningkatkan daya tawar petani. Banyak hal yang dapat diraih dengan berjalannya kelompok sebagai suatu kesatuan, diantaranya adalah mempercepat penyelesaian masalah budidaya, perbaikan harga jual, perluasan pasar, dan lainnya.

\section{Kesibukan Petani}

Petani responden maupun petani mangga di Kecamatan Sedong secara keseluruhan hampir semuanya memiliki pekerjaan sampingan selain usahatani mangga. Kebanyakan petani mangga juga melakukan usahatani padi. Lahan padi yang diusahakan terdiri dari lahan sendiri maupun lahan sewa. Petani mangga memiliki pekerjaan sampingan karena mangga adalah tanaman tahunan yang hanya panen maksimal dua kali dalam satu tahun. Pendapatan dari usahatani mangga dirasa petani kurang untuk mencukupi biaya hidup sehari-hari

\section{Kurangnya Tenaga Penyuluh}

Penyuluh merupakan sosok yang bertugas untuk mendampingi petani dalam melakukan kegiatan usahatani. Hasil penelitian Katon dkk (2017) menyebutkan bahwa terdapat pengaruh nyata antara kinerja penyuluh dengan perilaku petani. Saat ini Kabupaten Cirebon memiliki jumlah penyuluh yang tidak sebanding dengan jumlah daerah. Satu penyuluh di Kabupaten Cirebon memiliki kewajiban mendampingi 5 desa. Ading (45 Tahun) merupakan salah satu penyuluh yang bertugas di Kecamatan Sedong. Ia berkewajiban mendampingi 5 desa yaitu Putat, Sedong Kidul, Karangwuni, Panembangan, dan Kertawangun. Seharusnya satu penyuluh ditugaskan untuk satu desa, sehingga dapat fokus menangani satu kelompok tani. Namun permasalahan tersebut membuat jadwal 
penyuluhan dan pendampingan petani harus terbagi menjadi 5 kelompok. Tiap kelompok tani biasanya mendapatkan jatah penyuluhan setiap satu bulan sekali. Kurangnya tenaga penyuluh juga dinilai menjadi faktor penting yang menghambat perkembangan kelompok tani.

\section{KESIMPULAN}

Kegiatan kedua kelompok tani meliputi penyuluhan, program pengembangan agribisnis, pertemuan anggota, dan program bantuan. Terdapat beberapa perbedaan kegiatan yang dilakukan pada Kelompok Datar Indah dan Kelompok Samoja. Kelompok Datar Indah memilik kegiatan yang lebih banyak yaitu 15 kegiatan dalam satu tahun dengan mayoritas keikutsertaan anggota sebanyak 6-10 kali. Sedangkan pada Kelompok Samoja jumlah rata-rata kegiatan per tahun berjumlah 10 kegiatan, dengan mayoritas keikutsertaan anggota sebanyak 4-6 kali dalam satu tahun. Sementara itu, potensi yang dimiliki oleh kedua kelompok tani adalah peningkatan daya tawar petani, mempercepat pemecahan masalah, dan pengenalan teknologi baru. Sedangkan kendala yang dialami oleh kelompok tani berupa kurangnya motivasi petani, kurangnya kesadaran akan peran kelompok tani, kesibukan petani, dan kurangnya tenaga penyuluh.

\section{DAFTAR PUSTAKA}

Ali, A. (2017). Pengaruh Teknologi Pertanian Terhadap Produktivitas Hasil Panen Padi di Kecamatan Maritengngae Kabupaten Sidenreng Rappang. AKMEN Jurnal Ilmiah, 14(3).

Amin, Z.N. (2011). Penelitian Survey. Semarang: Universitas Negeri Semarang

Anisa, R. Y. (2017). Analisis Keberlanjutan Lembaga Keuangan Mikro Agribisnis (Lkm-A) Jaya Saiyo Kelurahan Bandar Buat Kecamatan Lubuk Kilangan Kota Padang (Doctoral Dissertation, Universitas Andalas).

Apriani, M., Rachmina, D., \& Rifin, A. (2018). Pengaruh Tingkat Penerapan Teknologi Pengelolaan Tanaman Terpadu (Ptt) terhadap Efisiensi Teknis USAhatani Padi. Jurnal Agribisnis Indonesia (Journal of Indonesian Agribusiness), 6(2), 119-132.

Azizah, M. N., Rasmikayati, E., \& Saefudin, B. R. (2019). Perilaku budidaya petani mangga dikaitkan dengan lembaga pemasarannya di Kecamatan Greged Kabupaten Cirebon. Jurnal Ilmiah Mahasiswa Agroinfo Galuh, 5(1), 987-998.

Badan Pusat Statistik. (2018). Provinsi Jawa Barat Dalam Angka 2017. Bandung: Cv. Filindo

Deviani, F., Rochdiani, D., \& Saefudin, B. R. (2019). Analisis Faktor-Faktor yang Mempengaruhi Produksi Usahatani Buncis Di Gabungan Kelompok Tani Lembang Agri Kabupaten Bandung Barat. Agrisocionomics: Jurnal Sosial Ekonomi Pertanian, 3(2), 165-173.

Elfadina, E. A., Rasmikayati, E., \& Saefudin, B. R. (2019). Analisis luas dan status penguasaan lahan petani mangga dikaitkan dengan perilaku agribisnisnya di Kecamatan Cikedung Kabupaten Indramayu. Jurnal Ilmiah Mahasiswa Agroinfo Galuh, 6(1), 69-79.

Hadipurwanta, J. (2017). Efektivitas Fungsi Kelembagaan Kelompok Tani Di Kecamatan Dumoga Timur Kabupaten Bolaang Mongondow.

Hartanti, D. S. (2010). Implikasi Penerapan Standar Operasional Prosedur (SOP) Terhadap Pendapatan Petani Mangga Gedong Gincu di Kecamatan Sedong, Kabupaten Cirebon Jawa Barat. Skripsi diterbitkan. Bogor: Institut Pertanian Bogor.

Katon, J. S. (2017). Pengaruh Kinerja Penyuluh Pertanian terhadap Perilaku Petani Padi Sawah di Kecamatan Gabus Kabupaten Pati (Doctoral dissertation, S1 Agribisnis Jurusan Pertanian). 
Kusumo, R. A. B., Rasmikayati, E., Mukti, G. W., Fatimah, S., \& Saefudin, B. R. (2018). FaktorFaktor yang mempengaruhi keputusan petani mangga dalam menggunakan teknologi off season di Kabupaten Cirebon. Mimbar Agribisnis: Jurnal Pemikiran Masyarakat Ilmiah Berwawasan Agribisnis, 4(1), 57-69.

Makawekes, N., Pangemanan, L. R., \& Memah, M. Y. (2016, June). Dinamika Kelompok Tani Cempaka di Kelurahan Meras Kecamatan Bunaken Kota Manado. In Cocos (Vol. 7, No. 3).

Nadapdap, H. J., \& Saefudin, B. R. (2020). Risiko Usahatani Mangga di Kecamatan Rembang Jawa Tengah. Jurnal Penelitian Pertanian Terapan, 20(2), 161-169.

Puslitbang Hortikultura. (2017). Dukungan Inovasi Balitbangtan Dalam Pengembangan Kawasan Agribisnis Manga Di Cirebon. Diakses Melalui Http://Hortikultura.Litbang.Pertanian.Go.Id/Berita-814-Dukungan-Inovasi-BalitbangtanDalam-Pengembangan-Kawasan-Agribisnis-Mangga-Di-Cirebon.Html

Puspitaningsih, O. S., Utami, B. W., \& Wijianto, A. (2018). Partisipasi kelompok tani dalam mendukung program-program pertanian berkelanjutan di Kecamatan Puring, Kabupaten Kebumen (Studi komparasi kelompok tani kelas lanjut dan pemula). Caraka Tani: Journal of Sustainable Agriculture, 31(2), 79-85.

Rachmah, A. D., Rasmikayati, E., \& Saefudin, B. R. (2019). Factors related to continuation of mango cultivation. Jurnal Pertanian, 10(2), 52-60.

Rasmikayati, E. (2018). Kajian Potensi dan Kendala dalam Proses Usahatani dan Pemasaran Mangga di Kabupaten Indramayu. Sosiohumaniora, 20(3), 215-221.

Rasmikayati, E., Elfadina, E. A., Kusumo, R. A. B., Saefudin, B. R., \& Supriyadi, S. (2020). Policy Analysis of Mango's Agribusiness Development (A Case in Cikedung District, Indramayu Regency). Jurnal Manajemen \& Agribisnis, 17(1), 52-52.

Rasmikayati, E., Saefudin, B. R., Nadapdap, H. J., \& Awaliyah, F. (2020). Agribusiness Behavior of Mango Farmers In The District of Panyingkiran Majalengka Regencybased On Mango Ownership. Sosiohumaniora, 22(2), 206-213.

Rasmikayati, E., Sari, A. F., Kusumo, R. A. B., Saefudin, B. R., \& Syamsiyah, N. (2020). FaktorFaktor Internal dan Eksternal yang Berhubungan Dengan Pemilihan Pasar Petani Mangga. Mimbar Agribisnis: Jurnal Pemikiran Masyarakat Ilmiah Berwawasan Agribisnis, 6(2), 936955.

Rasmikayati, E., Sulistyowati, L., Karyani, T., \& Saefudin, B. R. (2018). Dinamika Perilaku Agribisnis Petani Mangga Di Kecamatan Greged Kabupaten Cirebon. Paradigma Agribisnis, $1(1)$.

Saefudin, B. R., Rasmikayati, E., Dwirayani, D., Awaliyah, F., \& Rachmah, A. R. A. (2020). Fenomena Peralihan Usahatani Mangga Ke Padi Di Kecamatan Sedong, Kabupaten Cirebon, Jawa Barat. Paradigma Agribisnis, 2(2).

Swastika, D. K. (2016). Penguatan kelompok tani: langkah awal peningkatan kesejahteraan petani. Analisis Kebijakan Pertanian, 9(4), 371-390.

Wati, F., Rasmikayati, E., \& Saefudin, B. R. (2020). Analisis Hubungan Karakteristik Anggota Kelompok Tani dengan Penerapan Teknologi Off Season pada Kegiatan Usahatani Mangga di Kecamatan Sedong, Kabupaten Cirebon, Jawa Barat. Jurnal Ekonomi Pertanian dan Agribisnis, 4(4), 715-727. 